\title{
RED CELL DISTRIBUTION WIDTH (RDW) AS A MARKER OF DISEASE ACTIVITY IN PATIENTS WITH HAIRY CELL LEUKEMIA
}

\author{
Ladislav Chrobák ${ }^{1}$, Pavel Žák ${ }^{1}$, Karel Podzimek ${ }^{1}$, Pravoslav Stránsky $\hat{y}^{2}$ \\ Department of Clinical Hematology, Charles University, Faculty of Medicine and Teaching Hospital, Hradec Králové1; \\ (Head: prof. MUDr. J. Malý, CSc.) \\ Department of Medical Biophysics, Charles University, Faculty of Medicine, Hradec Králové2; \\ (Head: prof. MUDr. P. Stránský, CSc.)
}

\begin{abstract}
Summary: Red cell distribution width (RDW) was examined in 18 patients with hairy cell leukemia (HCL) treated with 2chlorodeoxyadenosine (2-CdA), in 5 patients treated with Interferon alpha (IFN-alpha) and in 9 patients subjected to splenectomy. Out of 18 patients treated with 2-CdA one patient was excluded of the study because of association of HCL with acquired sideroblastic anemia. In the remaining 17 patients the mean value of RDW before terapy was 18,8\% (range 13,5\% to $25,0 \%$ ) and dropped after successful theapy after 6 to 12 months to the mean value of $13,6 \%$ (range $11,2 \%$ to $17,9 \%$ ) and after 18 months to $13,4 \%$ (range $12,6 \%$ to $14,7 \%)(p=0,00015$ and $p=0,00049$ respectivelly). The hemoglobin level increased from the mean value of $119 \mathrm{~g} / 1$ (range $99 \mathrm{~g} / 1$ to $157 \mathrm{~g} / \mathrm{l}$ ) before therapy to the mean value of $145,9 \mathrm{~g} / \mathrm{l}$ (range 127 $\mathrm{g} / 1$ to $172 \mathrm{~g} / \mathrm{l}$ ) after 6 to 12 months and after 18 months to $147,8 \mathrm{~g} / 1$ (range $132 \mathrm{~g} / 1$ to $168 \mathrm{~g} / \mathrm{l})(\mathrm{p}=0,000017$ and $\mathrm{p}=$ 0,00036 respectively). The same trend was observed in the group of patients treated with IFN-alfa. The RDW decreased from the mean value of $21,3 \%$ (range $18,8 \%$ to $28,7 \%$ ) to the mean value of $15,3 \%$ (range $12,4 \%$ to $16,7 \%$ ), $(\mathrm{p}=0,031$ ). The hemoglobin level increased in this group of patients from the mean value of $115 \mathrm{~g} / 1$ (range $98 \mathrm{~g} / 1$ to $127 \mathrm{~g} / 1)$ to the mean value of $136 \mathrm{~g} / 1$ (range $127 \mathrm{~g} / 1$ to $146 \mathrm{~g} / 1)(\mathrm{p}=0,031)$. In 9 patients in complete hematologic remission 34 to 293 months after splenectomy the mean value of RDW was $13,9 \%$ (range $13,0 \%$ to $15,5 \%$ ). Conclusion: Increased RDW in HCL is associated with active disease and is reversible after successful therapy. This phenomenon has not been reported in the literature yet. Preliminary results show that the increase of RDW may be due to the dyserythropoiesis.
\end{abstract}

Key words: HCL; RDW; Dyserythropoiesis

Supported by Grant No 3690-2 IGA from the Ministry of Health of the Czech Republic.

\section{Introduction}

Hairy cell leukemia (HCL) is a chronic lymphoproliferative disorder characterized by abnormal mononuclear cells of B lymphocyte origin infiltrating bone marrow and spleen. Patients often present with some combination of anemia, neutropenia, thrombocytopenia and splenomegaly $(1,6,11)$. Anemia is very common and is observed in 75 to 80 percent of patients $(3,9,12)$. The mechanism of anemia has been attributed to the splenic sequestration with a substantial increase in splenic volume (13) and to the reduced red-cell production due to a diffuse bone marrow infiltration by tumor cells and bone marrow fibrosis $(4,15)$. Erythrokinetic studies revield that in addition to splenic sequestration and reduced red-cell production there is some reduction in red cell-survival (5). The anemia is usually normocytic or macrocytic with slight anisocytosis and poikilocytosis. The mean cell volume (MCV) is nearly always toward the upper limit of normal and often elevated (6). We have observed that red cell distribution width, which is indicative of anisocytosis, reflects in HCL the diseases activity (7).

\section{Patients and Methods}

The RDW values were assessed in 32 patients with HCL divided in three groups according to the therapy.

The diagnosis of HCL was based on the presence of morphologically characteristic cells in the peripheral blood and/or in the bone marrow, demonstration of the tartarat resistant acid phosphatase activity in the neoplastic cells (16), typical histologic pattern in bone marrow biopsies with infiltration by malignant cells characteristically surrounded by a rim of pale cytoplasm resulting in clearly separated nuclei (4). In all splenectomized patients the diagnosis was reconfirmed by the histologic finding in the spleen showing heavy infiltration of the red pulp by abnor- 
mal interdigitating mononuclear cells and the presence of blood-filled spaces lined by hairy cells, so called pseudosinuses (14).

\section{Response criteria to the therapy}

Complete hematologic remission (CR) required all of the following:

1) Complete absence of hairy cells in the peripheral blood.

2) Normalization of peripheral blood counts (hemoglobin level $\geq 120 \mathrm{~g} / 1$, white cell count $\geq 3 \times 10^{9} / 1$, absolute neutrophil count $\geq 1,5 \times 10^{9} / 1$, platelet count $\geq 100 \times 10^{9} / 1$, disappearance of retroperitoneal lymphadenopathy and hepatosplenomegaly by CT or US scan.

\section{Partial remission $(P R)$ required}

1) Failure of normalization in one of low peripheral blood counts.

2) Reduction grater than $50 \%$ of lymphadenopathy and/or hepatosplenomegaly. The Red Cell Width (RDW in \%) was determined using Coulter JT3 or Coulter STKS. Normal value $11,5-14,5 \%$.

\section{Patients}

Group 1 (see table 1): consisted of 18 patients treated by 2-chlorodeoxyadenosine (2-CdA). All patients received a single cycle of $2-\mathrm{CdA}$ at a dose of $0,1 \mathrm{mg} / \mathrm{kg} / \mathrm{d}$ by continous intravenous infusion for 7 days. Out of 18 patients there were 14 male and 4 female with an age range 39 to 82 years (median, 61,5 years). 11 patients were previously treated: 7 by splenectomy, 2 by splenectomy and IFN-alpha, 2 by repeated course of IFN-alpha because of relapse, in remaining 7 patients the 2-CdA therapy was the first treatment. All 18 patients responded to the therapy, in 16 complete hematologic remission was achieved, in one patient (M.W. No 11) the remission was partial because the platelet count increased after therapy only to $90 \times 10^{9} / 1$, but the hemoglobin level after therapy was within normal limits. Patient V.J. (No 15) reached the normal hemoglobin level after 18 months. Patient V.M. (No 6) was excluded from further assessement because of associated acquired sideroblastic anemia and will be considered separately.

Group 2 (see table 2) consisted of 5 patients treated by Interpheron-alpha. 3 patients were previously treated by splenectomy, 1 patient received the second course of IFNalpha because of relapse. Out of 5 patients there were 4 male and 1 female with an age range of 39 to 78 years (median, 58 years $)$.

Group 3 (see table 3) consisted of 9 patients treated by splenectomy with the follow up period after splenectomy between 34 and 293 months (median, 193 months). Out of 9 patients there were 5 male and 4 female with an age range between 51 to 71 years (median, 60 years). Bone marrow biopsy revieled interstitial infiltration by hairy cells in all patients. All patients have been after splenectomy in complete hematologic remission.
Table 1: Hemoglobin levels and RDW in Patiens with hairy cell leukemia treated with 2-chlorodeoxyadenosine

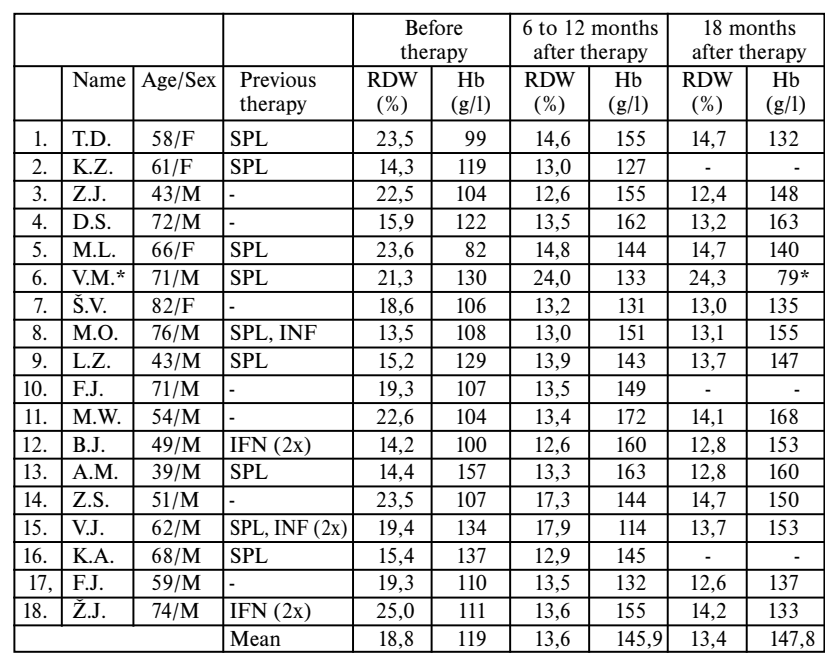

SPL - splenectomy

IFN - interferon-alpha

* - patient excluded of the study

Table 2: RDW and hemoglobin levels in patients with hairy cell leukemia treated with IFN-alpha

\begin{tabular}{|c|l|c|l|c|c|c|c|}
\hline \multicolumn{2}{|c|}{} & & \multicolumn{2}{c|}{ Before therapy } & \multicolumn{2}{c|}{ After 6 months } \\
\hline & Name & Age/Sex & $\begin{array}{l}\text { Previous } \\
\text { therapy }\end{array}$ & $\begin{array}{c}\text { RDW } \\
(\%)\end{array}$ & $\begin{array}{c}\text { Hb } \\
(\mathrm{g} / 1)\end{array}$ & $\begin{array}{c}\text { RDW } \\
(\%)\end{array}$ & $\begin{array}{c}\mathrm{Hb} \\
(\mathrm{g} / \mathrm{l})\end{array}$ \\
\hline 1. & O.M. & $76 / \mathrm{M}$ & SPL & 19,2 & 121 & 15,5 & 127 \\
\hline 2. & J.S. & $66 / \mathrm{M}$ & IFN-alpha & 18,8 & 127 & 16,7 & 127 \\
\hline 3. & M.H. & $39 / \mathrm{M}$ & SPL & 19,2 & 116 & 15,6 & 146 \\
\hline 4. & D.T. & $58 / \mathrm{F}$ & SPL & 20,7 & 98 & 16,7 & 141 \\
\hline 5. & J.B. & $49 / \mathrm{M}$ & - & 28,7 & 111 & 12,4 & 138 \\
\hline \multicolumn{3}{|c}{} & Mean & 21,3 & 115 & 15,3 & 136 \\
\hline
\end{tabular}

SPL - splenectomy

IFN - alpha-interferon-alpha

Table 3: Hemoglobin levels and RDW in patiens with hairy cell leukemia trated by splenectomy

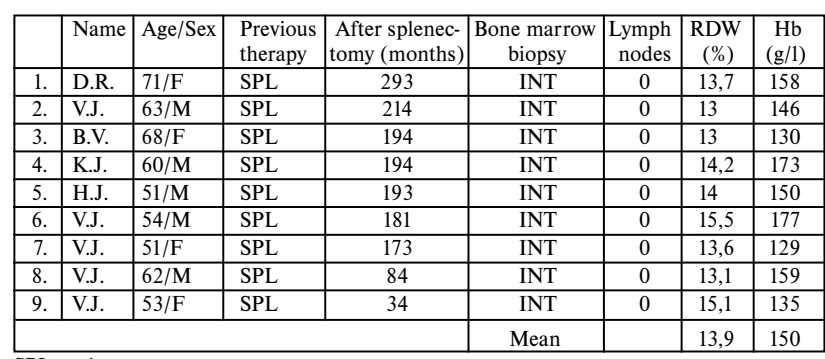

SPL - splenectomy

INT - interstitial infiltration

\section{Statistical analysis:}

For the statistical analysis of RDW and hemoglobin concentration procedures described in (10) were used. As we have two measurements on the same individual at different times two statistical tests were used. In the case when normality of differences could be accepted (by means of D'Agostino skewness, kurtosis and omnibus normality tes- 
ts) paired t-test was selected. If the assumption of normality was not valid Wilcoxon signed rank test was used.

In the first set of the data (17 and 14 subjects) when the result are compared after 6-12 months period and more than 18 months respectively it is again possible to reject the null hypothesis and accept the alternative one by means of Wilcoxon test. Values of RDW decreased significantly after the period of $6-12$ month $(p=0,00015)$ and after more than 18 months $(\mathrm{p}=0,00049)$.

In the case of $\mathrm{Hb}$ concentration it is possible to accept the null hypothesis as far as the normality of the differences is concerned and a paired t-test can be used. It allows to accept the alternative hypothesis and state that this variable increases $x$ ( $p=0,000017$ and $p=0,00036$ respectively).

It is not possible to verify the normality of the differences in the second set (data from 5 subjects) and Wilcoxon test allows to reject null hypothesis at 5\% significance level. Therefore we can accept the alternative hypothesis which states that RDW is lower $(p=0,031)$ and $\mathrm{Hb}$ concentration is higher after the treatment $(p=0,031)$.

\section{Results}

Group 1 (see table 1): Out of 17 assessed patients the RDW values before therapy were increased in 13 patients, within normal limits in 4 patients with a range between 13,5 to $25,0 \%$ (mean, $18,8 \%$ ). After 6 to 12 months of therapy the mean value of RDW was $13,6 \%$ (range 12,6 to $17,9 \%$ ), $(\mathrm{p}=0,00015)$ it was normal in 14 patients, slightly above the upper limit of normal value in 3 patients $(14,6 \%, 14,8 \%$, $17,3 \%$ ) and in the forth patient (V.J.,No 17: RDW 17,9\%) the normal RDW 13,7\% was reached after 18 months. The After 18 months RDW was within normal limits in 14 patients and only slightly above the upper limit of normal values in $3(14,7 \%, 14,7 \%, 14,7 \%)$. The mean value of RDW after 18 months was $13,4 \%$ (range $12,4 \%$ to $14,7 \%$ ), $(\mathrm{p}=0,00049)$.

The hemoglobin level simultaneously increased from the mean value of $119 \mathrm{~g} / 1$ (range $99 \mathrm{~g} / 1$ to $157 \mathrm{~g} / \mathrm{l}$ ) before therapy to the mean value of $145,9 \mathrm{~g} / 1$ (range $127 \mathrm{~g} / 1$ to 172 $\mathrm{g} / \mathrm{l}$ ) after 6 to 12 months and to $147,8 \mathrm{~g} / 1$ (range $132 \mathrm{~g} / 1$ to $168 \mathrm{~g} / \mathrm{l})$ after 18 months $(\mathrm{p}=0,00049$ and $\mathrm{p}=0,00036$ respectively).

Group 2 (see table 2): In the group of 5 patients treated with Interferon-alpha the RDW dropped from the mean value of $21,3 \%$ (range $18,8 \%$ to $28,7 \%$ ) before therapy to the mean value of $15,3 \%$ (range $12,4 \%$ to $16,7 \%$ ) after six months of therapy $(\mathrm{p}=0,031)$.

The hemoglobin level simultaneously increased from the main value of $115 \mathrm{~g} / 1$ (range $98 \mathrm{~g} / 1$ to $127 \mathrm{~g} / 1$ ) to the main value of $136 \mathrm{~g} / 1$ (range $127 \mathrm{~g} / 1$ to $146 \mathrm{~g} / \mathrm{l}),(\mathrm{p}=0,031)$.

Group 3 (see table 3): In the group of 9 patients treated by splenectomy all patients were in complete hematologic remission. Mean value of RDW was $13,9 \%$. The RDW was slightly above the upper limit of normal value in two patients $(15,1 \%$ and $15,5 \%)$ despite normal levels of hemoglo- bin $135 \mathrm{~g} / 1$ and $177 \mathrm{~g} / 1$ respectively. The RDW values before splenectomy were not accessible. The examination before splenectomy was performed with an automated instrument not giving RDW value.

\section{Discussion}

Anisocytosis is an increase in the variability of erythrocyte size beyond that which is observed in a healthy subject. In automated instruments the calculated value of RDW reflects very accurately the degree of anisocytosis and makes the comparison of its changes possible. RDW has been found to be increased in iron deficiency anemia, megaloblastic anemias, congenital and acquired dyserythropoietic anemias $(1,2,16,17)$. We have found that increased RDW in HCL was present in patients with an active disease and subsided after successful therapy with 2-CdA or IFN-alpha with a simultaneous rise of the hemoglobin levels. This phenomenon as far as we know has not been reported in the literature yet. Preliminary data show that the increased RDW may be due to the dyserythropoiesis (8). This finding is the subject of a further study and will be reported separately in more details.

\section{References}

1. Bain BJ. Blood cells. A practical quide. 2nd ed. Blackwell Science:Oxford, 1995:326.

2. Bessman JD, Gilmer PR, Gardner FH. Improved classification of the anemias by MCV and RDW. Am J Clin Pathol 1993;80:322-4.

3. Bouroncle B, Wiseman BK, Doan CA. Leukemic reticuloendotheliosis. Blood 1958;13:609-30.

4. Burke JS. The value of bone marrow biopsy in the diagnosis of hairy cell leukemia. Am J Clin Pathol 1978;70:876-84. 5. Castro-Malaspina H, Najean Y, Flandrin G. Erythrokinetic studies in hairy-cell leukaemia. $\mathrm{Br} \mathrm{J}$ Haematol 1979;42:189-97.

6. Cawley JC, Burns GF, Hayhoe GY. Hairy-Cell Leukaemia. Springer-Verlag:Berlin,New York, 1980:123.

7. Chrobák L, Žák P, Podzimek K et al. RDW in hairy cell leukemia (HCL): response to therapy and correlation with sIL-2R levels. (Abst.: 26th Congress of ISH,Singapore,2529.8.1996) Internat J Hematol 1996;64(Suppl. 1):S67,253. 8. Chrobák L, Žák P, Podzimek K et al. Dyserythropoiesis and increased RDW in hairy cell leukemia. The chronic leukemias. (Abst.: p.72) International Conference Prague, October 3-5,1996.

9. Golomb HM, Catovsky D, Golde DW. Hairy cell leukemia: A clinical review based on 71 cases. Ann Intern Med 1978;89:677-83.

10. Hintze JL. NCSS 6.0.1. User's Manual -I. Kaysville, 1995:404.

11. Jansen J, den Ottolander J, Velde $\mathbf{J}$ et al. Clinical differential diagnosis of hairy-cell leukemia. Acta Haemat 1980;64:181-94. 
12. Katayama I, Finkel HE. Leukemic reticuloendotheliosis. A clinicopathologic study with review of the literature. Am J Med 1974;57:115-26.

13. Lewis SM, Catovsky D, Hows JM et al. Splenic red cell pooling in hairy cell leukemia. Br J Haematol 1972;23:1-4. 14. Nanba K, Soban EJ, Bowling MC et al. Splenic pseudosinuses and hepatic angiomatous lesions. Distinctive feature of hairy cell leukemia. Am J Clin Pathol 1977;67: 415-26.

15. Podzimek K, Kerekeš Z, Chrobák L et al. The value of bone marrow biopsy in the prognosis of hairy cell leukemia (HCL). Neoplasma 1994;41:325-30.

16. Saxena S, Weiner JM, Carmel R. Red blood cell distribution width in untreated pernicious anemia. Am J Clin Pathol 1988;89:660-3.

17. Roberts GT, Badawi SB. Red cell distribution width in some hematologic diseases. Am J Clin Pathol 1985;83:222-6.
18. Vykoupil KF, Thiele J, Georgii A. Hairy cell leukemia: Bone marrow findings in 24 patients. Wirchow's Arch Pathol Anat 1976;370:273-89.

19. Yam LT, Li CY, Lam KW. Tartarate resistant acid phosphatase isoenzyme in the reticulum cell of leukemia reticuloendotheliosis. N Engl J Med 1971;284:357-60.

Submitted January 1998.

Accepted January 1998.

Prof. MUDr. Ladislav Chrobák, CSc., Department of Clinical Hematology, Charles University, Faculty of Medicine and Teaching Hospital, 50005 Hradec Králové, Czech Republic. 